\title{
İngilizce Öğretmenlerinin Alternatif Değerlendirme Yöntemlerini Kullanma Yeterliliklerinin İncelenmesi
}

\author{
DOI: 10.26466/opus.591260 \\ * \\ Mustafa Çelebi* - Beyza Nur Kuşuçuran** \\ *Doç. Dr, Erciyes Üniversitesi, Eğitim Fakültesi, Melikgazi/ Kayseri/Türkiye \\ E-Posta: mdcelebi@gmail.com ORCID: $0000-0002-0325-7528$ \\ **Öğretmen, Millî Eğitim Bakanlığı, Kürtün/Gümüşhane/Türkiye \\ E-Posta: bnur9696@gmail.com \\ ORCID: $\underline{0000-0002-3810-0619}$
}

\section{Öz}

Alternatif değerlendirmeler öğrenciyi merkeze alan yaklaşımlardır. Çă̆daş öğrenme-öğretme yaklaşımlarım benimseyen okullar genellikle öğreneni merkeze alan öğrenme-öğretme yaklaşımların uygulayıp alternatif değerlendirme yaklaşımların ve araçlarını tercih etmektedirler. Bu yaklaşımlar ve araçlar ö̆̆rencinin gerçek yaşamla bilgisi arasında bir bă̆lantı kurması ve problemlerle karşılaştığı zaman çözüm yolları bulabilmesi için firsatlar yaratır. Bu araştırmada İngilizce öğretmenlerinin alternatif ölçme ve değerlendirme tekniklerini ne sıklıkta kullandıkları çeşitli değişkenler açısından incelenmiştir ve bununla birlikte yeterlilikleri hakkında fikir sahibi olunmaya çalışılmıştır. Araştırma genel tarama modelinde bir çalışmadır. Araştırmanın evrenini 2018-2019 eğitim öğretim yılında görev yapmakta olan İngilizce öğretmenleri oluşturmaktadır. Basit rastgele örnekleme yöntemi ile belirlenen 253 İngilizce öğretmeni araştırmanın örneklem grubunu oluşturmaktadır. Çalışmada veri toplama aracı olarak İngilizce öğretmenlerinin alternatif ve geleneksel değerlendirme yöntemlerini kullanma sıklıklarına ilişkin bir anket uygulanmıştır. Kullanılan veri toplama aracı daha önce yapılmış olan bir yüksek lisans tezinden alınıp uyarlanmıştır. Araştırma sonucu İngilizce öğretmenlerinin alternatif değerlendirmeler konusunda bilgi sahibi ve yeterli olduğuna ulaşılmış sadece bu yöntemleri tercih etme sıkliklarının farklılaştığı görülmüş̧ür. Hatta bu öğretmenlerin alternatif değerlendirme yöntemiyle birlikte geleneksel yöntemlerin bazılarından da hiç vazgeçmediği sonucuna ulaşılmıştır. Hizmet içi eğitimde ölçme ve değerlendirme dersi alma değişkeni haricinde diğer bütün değiş̧kenlerde alternatif değerlendirme yöntemlerini kullanım sıklı̆̆ında anlamlı farklılıklara ulaşılmıştır.

Anahtar Kelimeler: Alternatif Değerlendirme, Öğretmen Performansl, Değerlendirme Yöntemleri 


\title{
Examining The Competencies of English Teachers Using Alternative Assessment Methods
}

\begin{abstract}
Alternative assessments are approaches that center the student. Schools that adopt contemporary learning-teaching approaches generally apply learning-teaching approaches centered on the learner and prefer alternative assessment approaches and tools. These approaches and tools create opportunities for the student to make a connection between real life and knowledge and to find solutions when faced with problems. In this study, the frequency of using alternative evaluation and assessment techniques of English teachers is examined in terms of various variables. The study is a general survey model. The population of the study consists of English teachers who are working in 2018-2019 academic year. The sample group of the study consists of 253 English teachers who are determined by simple random sampling method. In the study, a questionnaire was applied about the frequency of using alternative and traditional assessment methods of English teachers as data collection tools. The data collection tool was taken from a previous master thesis and adapted. As a result of the research, it was found that English teachers were knowledgeable and sufficient about alternative assessments and it had been observed that the frequency of teachers choosing these methods was different. In fact, it has been concluded that these teachers never give up some of the traditional methods together with the alternative assessment method. Significant differences were found in the frequency of using alternative assessment methods in all variables except in the in-service training variable.
\end{abstract}

Keywords: Alternative Assessment, Teacher Performance, Assessment Methods 


\section{Giriş}

Eğitim sisteminde yıllar içerisinde birçok değişiklik yapılmış, yeni uygulamalar eklenmiş, ders içerikleri ve programları değiştirilmiş, farklı ölçme-değerlendirme yöntemleri kullanılmaktadır. Bu değişimlere uyum sağlamak adına öğretmenlerde bazı noktalarda kendilerini yenilemek, derste kullandıkları yöntem ve tekniklerini yeni ders içeriğine ve ölçme değerlendirme durumlarına göre değiştirmek durumunda kalmışlardır. Bahsedilen tüm bu değişimlerin uygulanabilmesi öğretmenler, öğrenciler ve idareciler açısından uzun bir süreç gerektirmektedir. Süreç sonunda değişen uygulamaların ve yöntemlerin işe yararlılığının görülebilmesi, bilim çağının özelliklerine uygun nitelikli insan yetiştirilip yetiştirilmediğine bağlıdır.

Uzun yıllar boyunca öğretim programlarında yer alan bilgilerin doğrudan öğretilmesi ve bu bilgilerin olduğu gibi öğrenilip öğrenilmemesi eğitim camiasında önemini korumaktadır. Zelyurt ve Özbek (2018) "Alternatif Değerlendirme Araçlarına Yönelik Öğretmen Görüşleri" adlı yaptıkları araştırmada, okulların eğitim politikalarını daha çok bilgileri olduğu gibi ver öğrenci öğrensin, yeri geldiğinde kullansın anlayışına dayandırmışlardır ve bu anlayışın kaçınılmaz bir sonucu olarak ezberci sistemin ortaya çıtı̆̆ını ifade etmiştir. Böylelikle uygulanan öğretim etkinlikleri ve ölçme değerlendirme sistemleri de daha çok hatırlamaya ve ezbere dayandırılmaktadır. Bu durum birçok bireyin üst düzey düşünme özelliklerinin (problem çözme, eleştirel düşünme, karar verme, yaratıcılık gibi) gelişmesine engel olmaktadır (Kutlu, Doğan ve Karakaya, 2017).

Eğitim programları; hedef, içerik, eğitim durumu ve ölçme-değerlendirme olmak üzere dört ana bileşenden oluşmaktadır. Burke ve Oliva, son halka olan ölçme ve değerlendirmenin program tasarım sürecinde en önemli öge olduğunu söylemektedirler. (Şahin ve Öztürk, 2014). Ölçme ve değerlendirme eğitim durumlarının belli bir düzen içerisinde yürütülmesini sağlayan, öğretmenlere öğretim süreçleri hakkında bilgi verip geri bildirim sağlayan önemli bir basamaktır. Ölçme ve değerlendirme birçok araştırmacı tarafından tanımlanmaktadır. Örneğin Karaaslan (2015), “Ölçme, ölçülen niteliklerin aralarındaki ilişkileri koruyacak şekilde bu niteliklere sayı veya sembollerin atanması işlemleri olarak; değerlendirme ise, öğretme ve öğrenmenin etkililiğini belirlemek 
amacı ile yapılan, eğitimle ilgili verilerin toplanmasını ve yorumlanmasını içeren çok adımlı, sistematik bir süreç olarak tanımlanır ve öğretim sürecinin son evresidir." demiştir. Bir başka araştırmacı ise basit anlamda ölçme, niteliklerin sayısallaştırılmasıdır; geniş anlamda ise, gözlenen niteliklerin sayı, sembol, kod, derece veya unvan ile ifade edilmesi olduğunu belirtmektedir (Karip, 2008).

Değerlendirme ile ilgili farklı tanımlamalar bulunmaktadır ve bunlardan biri, açık bir sistem olarak ele alınan eğitimin çıktılarını, belirlenen ölçütlere göre inceleyerek sistemin işleyişi hakkında gözlem yapma ve bir yargıya ulaşmak ifadesidir (Demirel 2006, Akt. Şahin ve Atasoy 2018). Başka bir tanımda ise, değerlendirmenin ölçümlerden bir anlam çıkarmak ve ölçülen özellikler hakkında bir değer yargısına ulaşmak olduğu ya da ölçüm sonuçlarını anlamlandırabilmek için bir ölçütle karşılaştırılması yani buna göre değerlendirmenin bir ölçüm ile bir ölçütün karşılaştırılmasının gerekliliği olduğu ifade edilmektedir (Karip, 2008).

Test/sınav ve değerlendirmenin birbirinden oldukça farklı kavramlar olduğu unutulmamalıdır. Test resmi ve genellikle standartlaştırılmış olsa $\mathrm{da}$, değerlendirme öğrencilerin ne bildiği ve neler yapabildikleri hakkında bilgilere dayanmaktadır (Dikli, 2003). Bu konu da Nasab(2015)'de ölçme ve değerlendirmenin yani sınavın ayrı tutulması gerektiğini söylemiş ve değerlendirmenin farklı zamanlarda ve farklı ortamlarda çeşitli bilgi toplama yöntemleri yoluyla öğrencilerin sahip olduğu en gelişmiş bilginin gayri resmi olarak toplanmasıdır, diye belirtmiştir.

İçinde bulunduğumuz eğitim öğretim sisteminin de önemli bir parçası olan ölçme ve değerlendirme, eğitim programlarındaki yaklaşımların değişmesine paralel olarak zaman içerisinde bir takım değişikliklere uğramaktadır. Değişen programla birlikte bilişsel ve davranışsal yaklaşımların yanına yapılandırmacı yaklaşımların ilave edilmesi gerekliliği belirtilmektedir. Yapılandırmacı eğitimin en önemli özelliği öğrenenin bilgiyi yapılandırmasına, oluşturmasına, yorumlamasına ve geliştirmesine fırsat vermesidir (Kuran, 2009). Bu yaklaşım öğretmen yerine öğrenciyi merkeze almaktadır. Brooks ve Brooks (1999)'a göre yapılandırmacı yaklaşımda öğrenmenin kontrolü bireydedir ve öğrenmeye öğretmeniyle birlikte yön verir. Öğrenciler geleneksel öğrenme ortamlarında pasif bir role sahiptir. Aktif olmayan tutum ve davranışları, öğrencilerin sınıf içer- 
isinde sorumluluk almasını engellemektedir. Yapılandırmacı öğrenme ortamlarında öğrenciler daha fazla sorumluluk üstlenir ve gelecek öğrenmelerini kolaylaştıracağ1 düşüncesinden yola çıkarak düşünme yapılarının gelişimine katkıda bulunabilecek her türlü fırsatı değerlendirmeye çalışırlar (Karaaslan, Fen ve Teknoloji Öğretmenlerinin Alternatif Ölçme Değerlendirme Tekniklerini Uygulamadaki Yeterlilikleri, 2015). Aynı zamanda yapılandırmacı yaklaşım, bireysel farklılıkları dikkate alır ve bireyin kendine özgü özelliklerini ön plana çıkararak herkesin sahip olduğu bilgilerle yeni aldığı bilgileri kendine özgü biçimde yapılandırdığını öne sürer (Duran, Mıhladız, ve Ballıel, 2013). Bu konuyla ilgili (Özenç ve Çakır, 2015) ilköğretim programının (MEB, 2005) temelini oluşturan yapılandırmacı felsefeyle öğretim yöntem ve tekniklerinin mümkün olduğunca çeşitlendirilmesi, ölçme ve değerlendirmede de öğrencilere bilgi, beceri ve tutumlarını sergileyebilecekleri çoklu değerlendirme fırsatları sunulmasının gerektiğini ifade etmektedir. Çoklu değerlendirme denildiğinde ise akla gelen klasik, geleneksel ölçme ve değerlendirmeden ziyade alternatif değerlendirmedir. Geleneksel ölçme ve değerlendirme teknikleri ile öğrencilerin sadece sahip oldukları bilgi düzeyleri değerlendirilirken alternatif ölçme ve değerlendirme teknikleri ile öğrencilerin bilgileri, becerileri, tutumları, ilgi ve ihtiyaçları gibi çok yönlü özellikleri değerlendirilebilir (Özenç ve Çakır, 2015). Geleneksel değerlendirme yöntemleri ürün odaklı olup, süreci ihmal etmektedir.

\begin{tabular}{|c|c|}
\hline Geleneksel Değerlendirme & Alternatif Değerlendirme \\
\hline $\begin{array}{ll}\text { - } & \text { Tek düze- Standartlaşmış sınavlar } \\
\text { - } & \text { Zaman kısıtlamalı, çoktan seçmeli } \\
\text { - } & \text { Bağlamdan ayrı sınav maddeleri } \\
\text { - } & \text { Geri dönüt için puanlar/notlar } \\
& \text { yeterli } \\
\text { - } & \text { Doğru cevap odaklı } \\
\text { - } & \text { Sonuç değerlendirme } \\
\text { - } & \text { Etkileşim yoktur } \\
\text { - } & \text { Dişsal güdülemeye teşvik eder }\end{array}$ & 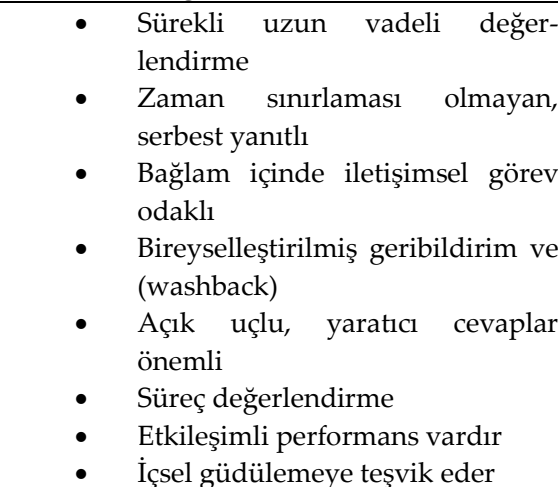 \\
\hline
\end{tabular}

Kaynak: Language Assessment Principles and Classroom Practices - H. Douglas Brown (Brown, 2004) 
Türkçe öğretmenlerinin alternatif ölçme ve değerlendirme kullanım sıklıkları ile ilgili yapılan bir araştırmada, öğrenci başarısını değerlendirirken birkaç yöntemin birlikte kullanılmasının güvenilirliği arttıracağını ve bu yüzden geleneksel ölçme araçlarının yanı sıra öğretmen gözlem formları, öğrenci ürün dosyaları, öz değerlendirme formları gibi alternatif ölçme-değerlendirme araçlarının da kullanılmasının yararlı olacağı belirtilmektedir (Göçer 2013). Bu amaçla sürece vurgu yapan, süreci önemseyen ve değerlendiren alternatif ölçme-değerlendirme yöntemlerinin kullanılması her öğrencinin eğitim-öğretim sürecinin daha sağlıklı ve sağlam yapılanması için önemlidir. Alternatif ölçme-değerlendirme yöntemleri sayesinde öğrencinin başarısı ve başarısızlı̆̆ı değerlendirilirken öğrencinin performansı ve ne bildiği değerlendirme sürecine katılır (Yiğit ve Kırımlı, 2015). Burada önemli olan öğrencilerin neyi bilmediğinden ziyade onların neleri bildiklerinin ortaya çıkartılmasıdır.

\section{Araştırmanın Amacı}

$\mathrm{Bu}$ araştırma İngilizce öğretmenlerinin alternatif değerlendirme yöntemlerini kullanma sıklıklarını bazı değişkenlere göre araştırma ve inceleme amacıyla yapılmıştır. Bu amaçla aşağıdaki sorulara cevap aranmıştır;

1- İngilizce öğretmenlerinin alternatif değerlendirme yöntemlerine yönelik yeterlik algıları nedir?

2- İngilizce öğretmenleri alternatif değerlendirme yöntemlerini(gözlem, portfolyo, kendini değerlendirme, yaşıtın değerlendirme, proje, hikâye tekrarlı anlatım, dramatize etme, oyunlar, günlükler, gösterimler, sergiler, konferanslar, sesli düşünme ve tartışma)

a) Cinsiyete,

b) Mezun olunan okula,

c) Lisans ve/veya lisansüstü eğitim esnasında ölçme ve değerlendirme ile ilgili ders alım durumuna,

d) Ölçme ve değerlendirme tekniklerine ilişkin hizmet içi eğitim kursuna katılma durumuna göre ne sıklıkta kullanmaktadır? 


\section{Yöntem}

\section{Araştırma Modeli}

İngilizce öğretmenlerinin alternatif değerlendirme yöntemlerini kullanma sıklıkları ve yeterliliklerini incelemek amacıyla yapılan bu çalışma genel tarama modelinde, bir konudaki mevcut durumu ortaya koyan betimsel bir çalışmadır. Tarama modelleri, bir grubun belirli özelliklerini belirlemek için verilerin toplanmasını amaçlayan araştırmalardır. Var olan durumu o durumun fotoğrafını çekerek betimlemeyi amaçlayan yaklaşımlardır. Var olan durumu değiştirme, etkileme çabası gösterilmez (Zelyurt ve Özbek, 2018).Verilerin çok fazla kişiden toplanmasından dolayı bu araştırmalar deneysel çalışmalara göre daha geniş gruplar üzerinde yürütülmektedir.

\section{Evren ve Örneklem}

Bu araştırmanın evrenini; 2018-2019 öğretim yılında Türkiye'de ilkokul, ortaokul ve lise kademesinde görev yapmakta olan tüm İngilizce öğretmenleri oluşturmaktadır. Örneklemini ise bu okullarda görev yapan 253 İngilizce öğretmeni oluşturmaktadır. Örneklem, çalışma evreni içinden basit olasılıklı (rastgele) örnekleme yoluyla seçilmiştir.

Tablo 1. Araştırmaya katılan İngilizce öğretmenlerine dair veriler

\begin{tabular}{llll}
\hline Değişken & Gruplar & f & \% \\
\hline \multirow{2}{*}{ Cinsiyet } & Kadın & 198 & 78,3 \\
& Erkek & 55 & 21,7 \\
\hline \multirow{3}{*}{ Mezun Olunan Okul } & Eğitim Fakültesi & 155 & 61,3 \\
& Fen Edebiyat Fakültesi & 67 & 26,5 \\
& Lisansüstü & 31 & 12,3 \\
\hline Lisans Eğitiminde Ölçme Değer- & Evet & 230 & 90,9 \\
lendirme Dersi Almak & Hayır & 23 & 9,1 \\
\hline Ölçme Değerlendirme Hizmetiçi & Evet & 56 & 22,1 \\
Kursuna Katılma & Hayır & 197 & 77,9 \\
\hline
\end{tabular}

Basit olasılıklı örnekleme yönteminde evrende bulunan tüm birimler, örnekleme seçilmek için bağımsız ve eşit şansa sahiptir (Büyüköztürk, Kılıç Çakmak, Akgün, Karadeniz ve Demirel, 2018). Araştırmaya katılan 
ortaokul öğretmenlerinin çeşitli değişkenlere göre bilgileri aşağıdaki tabloda (Tablo1) gösterilmektedir.Tabloya göre araştırmaya katılan İngilizce öğretmenlerinin büyük bir kısmını $(\% 78,3)$ kadın öğretmenler oluşturmaktadır. Mezun olunan okullardaki gruplar incelendiğinde ise en fazla Eğitim Fakültesi mezunları $(\% 61,3)$ bulunurken bu siralamayı Fen Edebiyat Fakültesi mezunları $(\% 26,5)$ takip etmektedir. Katılımcların neredeyse hepsi $(\% 90,9)$ lisans eğitimleri esnasında ölçme ve değerlendirme dersi aldığını ifade ederken ölçme ve değerlendirme ile ilgili hizmet içi kurslara katılan öğretmenlerin sayısı (56) katılmayan öğretmenlere (197) kıyasla oldukça azdır.

\section{Veri Toplama Aracı}

Çalışmada İngilizce öğretmenlerine araştırmanın amacına uygun olarak hazırlanan alternatif ve geleneksel değerlendirme yöntemleri kullanım sıklığı anketi uygulanmıştır. Kullanılan veri toplama aracı Yüzüncü Yıl Üniversitesi Fen Bilgisi Eğitimi Bilim Dalında yapılmış bir yüksek lisans tezinden alınıp uyarlanmıştır(Karaaslan, Yüksek Lisans Tezi, 2015).

\section{Verilerin Analizi}

Yapılan uygulama neticesinde elde edilen veriler, kontrol edilip gerekli düzenlemeler yapıldıktan sonra bilgisayar ortamına aktarılmıştır. Aktarılan veriler SPSS programı ile analiz edilmiştir. Araştırmanın amacına uygun olarak elde edilen verilerin analizinde öğretmenlere yönelik kişisel bilgilerde ve maddelerde frekans ve yüzde gibi tekniklerden yararlanılmıştır. Bunun yanı sıra araştırmada değişkenler arasındaki ilişkileri analiz etmek ve anlamlandırmak için çapraz tablolar kullanılmıştır. 
İngilizce Öğretmenlerinin Alternatif Değerlendirme Yöntemlerini Kullanma Yeterliliklerinin İncelenmesi

\section{Bulgular}

Tablo 2. Ingilizce öğretmenlerinin alternatif ölçme ve değerlendirme yöntemlerini cinsiyete göre kullanım siklıkları.

\begin{tabular}{|c|c|c|c|c|c|c|c|c|}
\hline \multirow{2}{*}{$\begin{array}{l}\text { Değerlendirme } \\
\text { Türü }\end{array}$} & \multirow[t]{2}{*}{ Gruplar } & \multicolumn{2}{|c|}{ Hiçbir Zaman } & \multicolumn{2}{|c|}{ Bazen } & \multicolumn{2}{|c|}{ Her zaman } & \multirow[t]{2}{*}{$\mathbf{X}^{2}$} \\
\hline & & $\mathrm{f}$ & $\%$ & $\mathrm{f}$ & $\%$ & $\mathrm{f}$ & $\%$ & \\
\hline \multirow{3}{*}{ Gözlemler } & Kadın & 22 & $\% 11$ & 29 & $\% 14,6$ & 147 & $\% 74,2$ & \\
\hline & Erkek & 3 & $\% 5,5$ & 16 & $\% 29$ & 36 & $\% 65,5$ &, $032^{*}$ \\
\hline & Toplam & 25 & & 45 & & 183 & & \\
\hline \multirow[t]{3}{*}{ Portfolyolar } & Kadın & 29 & $\% 14,6$ & 126 & $\% 63,6$ & 43 & $\% 21,7$ & \\
\hline & Erkek & 8 & $\% 14,5$ & 41 & $\% 74,5$ & 6 & $\% 11$ & 185 \\
\hline & Toplam & 37 & & 167 & & 49 & & \\
\hline \multirow{3}{*}{$\begin{array}{l}\text { Kendini değer- } \\
\text { lendirme }\end{array}$} & Kadın & 20 & $\% 10$ & 85 & $\% 43$ & 93 & $\% 47$ & \\
\hline & Erkek & 2 & $\% 3,6$ & 22 & $\% 40$ & 31 & $\% 56,4$ & 231 \\
\hline & Toplam & 22 & & 107 & & 124 & & \\
\hline Yaşıtını & Kadın & 51 & $\% 26$ & 93 & $\% 47$ & 54 & $\% 27$ & \\
\hline \multirow[t]{2}{*}{ Değerlendirme } & Erkek & 5 & $\% 9$ & 43 & $\% 78$ & 7 & $\% 13$ &, $000^{*}$ \\
\hline & Toplam & 56 & & 136 & & 61 & & \\
\hline \multirow[t]{3}{*}{ Projeler } & Kadın & 11 & $\% 5,6$ & 114 & $\% 57,6$ & 73 & $\% 37$ & \\
\hline & Erkek & 0 & $\% 0$ & 43 & $\% 78$ & 12 & $\% 22$ &, $012^{*}$ \\
\hline & Toplam & 11 & & 157 & & 85 & & \\
\hline \multirow{3}{*}{$\begin{array}{l}\text { Hikâye } \\
\text { Tekrarlı } \\
\text { Anlatım }\end{array}$} & Kadın & 66 & $\% 33$ & 112 & $\% 78$ & 20 & $\% 10$ & \\
\hline & Erkek & 16 & $\% 29$ & 31 & $\% 21,7$ & 8 & $\% 14,5$ & 604 \\
\hline & Toplam & 82 & & 143 & & 28 & & \\
\hline \multirow{3}{*}{$\begin{array}{l}\text { Dramatize } \\
\text { Etme }\end{array}$} & Kadın & 25 & $\% 12,6$ & 98 & $\% 49,5$ & 75 & $\% 38$ & \\
\hline & Erkek & 6 & $\% 11$ & 32 & $\% 58$ & 17 & $\% 31$ &, 519 \\
\hline & Toplam & 31 & & 130 & & 92 & & \\
\hline \multirow[t]{3}{*}{ Oyunlar } & Kadın & 7 & $\% 3,5$ & 77 & $\% 39$ & 114 & $\% 57,6$ & \\
\hline & Erkek & 0 & $\% 0$ & 36 & $\% 65,5$ & 19 & $\% 34,5$ &, $001^{*}$ \\
\hline & Toplam & 7 & & 113 & & 133 & & \\
\hline \multirow{3}{*}{$\begin{array}{l}\text { Günlükler } \\
\text { Dergiler }\end{array}$} & Kadın & 88 & $\% 43,4$ & 101 & $\% 51$ & 11 & $\% 5,6$ & \\
\hline & Erkek & 22 & $\% 40$ & 31 & $\% 56,4$ & 2 & $\% 3,6$ & 718 \\
\hline & Toplam & 108 & & 132 & & 133 & & \\
\hline \multirow[t]{3}{*}{ Gösterimler } & Kadın & 24 & $\% 12$ & 90 & $\% 45,5$ & 84 & $\% 42,4$ &, $011^{*}$ \\
\hline & Erkek & 6 & $\% 11$ & 37 & $\% 29$ & 12 & $\% 22$ & \\
\hline & Toplam & 30 & & 127 & & 96 & & \\
\hline \multirow[t]{3}{*}{ Sergiler } & Kadın & 102 & $\% 51,5$ & 88 & $\% 44,4$ & 8 & $\% 4$ & ,315 \\
\hline & Erkek & 30 & $\% 54,5$ & 25 & $\% 45,5$ & 0 & $\% 0$ & \\
\hline & Toplam & 7 & & 113 & & 133 & & \\
\hline \multirow[t]{3}{*}{ Konferanslar } & Kadın & 91 & $\% 46$ & 92 & $\% 46,7$ & 14 & $\% 7$ & 206 \\
\hline & Erkek & 31 & $\% 56,4$ & 23 & $\% 42$ & 1 & $\% 2$ & \\
\hline & Toplam & 122 & & 115 & & 133 & & \\
\hline \multirow[t]{3}{*}{ Sesli Düşünme } & Kadın & 91 & $\% 46$ & 92 & $\% 46,7$ & 14 & $\% 7$ & 206 \\
\hline & Erkek & 31 & $\% 56,4$ & 23 & $\% 42$ & 1 & $\% 2$ & \\
\hline & Toplam & 122 & & 115 & & 133 & & \\
\hline \multirow[t]{3}{*}{ Tartışmalar } & Kadın & 19 & $\% 10$ & 114 & $\% 58,8$ & 61 & $\% 31,4$ &, 539 \\
\hline & Erkek & 3 & $\% 5,5$ & 32 & $\% 58,2$ & 20 & $\% 36,4$ & \\
\hline & Toplam & 22 & & 146 & & 81 & & \\
\hline
\end{tabular}


Tablo 2 incelendiğinde İngilizce öğretmenlerinin alternatif ölçme ve değerlendirme yöntemlerini cinsiyete göre kullanım sıklıklarında gözlem, yaşıtını değerlendirme, projeler, oyunlar, gösterimler ve sesli düşünme yöntemlerinde anlamlı farklılıklar olduğu görülmüştür. Gözlem, oyunlar ve gösterimler yöntemlerini kadın öğretmenler her zaman tercih ettiklerini söylerken; kadın öğretmenlerin \%47'si erkek öğretmenlerin ise \%78'i yaşıtını değerlendirme yöntemini bazen kullanmakta olduklarını belirtmiştir. Sesli düşünmede ise kadın öğretmenlerin \%55'i bu yöntemi bazen kullandıkları şeklinde yanıt verirken erkek öğretmenlerin \%43'ü yani çoğunluğu hiçbir zaman şeklinde yanıt vermiştir.

Tablo 3. Ingilizce öğretmenlerinin geleneksel ölçme değerlendirme yöntemlerini cinsiyete göre kullanım sıklıkları.

\begin{tabular}{|c|c|c|c|c|c|c|c|c|}
\hline \multirow{2}{*}{$\begin{array}{l}\text { Değer- } \\
\text { lendirme } \\
\text { Türü }\end{array}$} & \multirow[b]{2}{*}{ Gruplar } & \multicolumn{2}{|c|}{ Hiçbir Zaman } & \multicolumn{2}{|c|}{ Bazen } & \multicolumn{2}{|c|}{ Her zaman } & \multirow[t]{2}{*}{$\mathrm{X}^{2}$} \\
\hline & & $\mathrm{f}$ & $\%$ & $\mathrm{f}$ & $\%$ & $\mathrm{f}$ & $\%$ & \\
\hline \multirow{3}{*}{$\begin{array}{l}\text { Yazılı } \\
\text { Yoklama }\end{array}$} & Kadın & 17 & 8,7 & 34 & 17,3 & 145 & 74 & \multirow{3}{*}{,077 } \\
\hline & Erkek & 0 & 0,0 & 10 & 18,2 & 45 & 82 & \\
\hline & Toplam & 17 & & 44 & & 190 & & \\
\hline \multirow{3}{*}{$\begin{array}{l}\text { Sözlü } \\
\text { Yoklama }\end{array}$} & Kadın & 25 & 12,6 & 78 & 39,4 & 95 & 48 & \multirow{3}{*}{, $024^{*}$} \\
\hline & Erkek & 5 & 9,0 & 33 & 60 & 17 & 31 & \\
\hline & Toplam & 30 & & 111 & & 112 & & \\
\hline \multirow{3}{*}{$\begin{array}{l}\text { Çoktan } \\
\text { Seçmeli Test }\end{array}$} & Kadın & 10 & 5 & 100 & 50,5 & 88 & 44,4 & \multirow{3}{*}{,063 } \\
\hline & Erkek & 6 & 11 & 33 & 60 & 16 & 29 & \\
\hline & Toplam & 16 & & 133 & & 104 & & \\
\hline \multirow{3}{*}{$\begin{array}{l}\text { Doğru- } \\
\text { Yanlış } \\
\text { Soruları }\end{array}$} & Kadın & 11 & 5,6 & 88 & 44,4 & 99 & 50 & \multirow{3}{*}{, $001^{*}$} \\
\hline & Erkek & 0 & 0 & 39 & 71 & 16 & 29 & \\
\hline & Toplam & 11 & & 124 & & 115 & & \\
\hline \multirow{3}{*}{$\begin{array}{l}\text { Kisa Cevapli } \\
\text { Sorular }\end{array}$} & Kadın & 6 & 3 & 80 & 40,4 & 112 & 56,6 & \multirow{3}{*}{, $000^{*}$} \\
\hline & Erkek & 3 & 5 & 39 & 71 & 13 & 23,6 & \\
\hline & Toplam & 9 & & 119 & & 125 & & \\
\hline \multirow{3}{*}{$\begin{array}{l}\text { Eşleştirme } \\
\text { Soruları }\end{array}$} & Kadın & 1 & 0,5 & 73 & 37 & 124 & 62,6 & \multirow{3}{*}{, $020^{*}$} \\
\hline & Erkek & 2 & 3,6 & 28 & 51 & 25 & 45,5 & \\
\hline & Toplam & 3 & & 101 & & 149 & & \\
\hline
\end{tabular}

Tablo 3 incelendiğinde ise İngilizce öğretmenlerinin geleneksel ölçme değerlendirme yöntemlerini cinsiyete göre kullanım sıklıklarında sözlü yoklama, doğru-yanlış soruları, kısa cevaplı soruları ve eşleştirme soruları yöntemlerinin kullanım sıklıkları doğrultusunda alınan cevaplarda anlamlı farklılıklar görülmüştür. Kadın öğretmenlerin \%48'i sözlü yoklamayı her zaman tercih ederken erkek öğretmenlerin \%60'ı bazen şeklinde 
cevap vermiş̧ir. Kadın öğretmenlerin \%50'si doğru-yanlış sorularını kullanma sıklıklarına her zaman şeklinde yanıt verirken erkek öğretmenlerin \%71'i bazen yanıtını vermiştir. Kısa cevaplı soruların kullanım sıklığına bakıldığında ise kadınların \%56'sı her zaman, erkeklerin \%71'i bazen cevabın vermiştir. Son olarak eşleştirme sorularının kullanım sıklıklarına bakıldığında kadınların \%62'si her zaman, erkeklerin \%51'i bazen cevabını vermiştir.

Tablo 4. İngilizce öğretmenlerinin alternatifölçme ve değerlendirme yöntemlerini mezun oldukları okullara göre kullanım siklıkları.

\begin{tabular}{|c|c|c|c|c|c|c|c|c|}
\hline \multirow{2}{*}{$\begin{array}{l}\text { Değer- } \\
\text { lendirme } \\
\text { Türü }\end{array}$} & \multirow{2}{*}{ Gruplar } & \multirow{2}{*}{\multicolumn{2}{|c|}{$\begin{array}{l}\text { Hiçbir Zaman } \\
\text { f\% }\end{array}$}} & \multirow{2}{*}{\multicolumn{2}{|c|}{$\begin{array}{l}\text { Bazen } \\
\mathrm{f} \%\end{array}$}} & \multicolumn{2}{|c|}{ Her zaman } & \multirow[t]{2}{*}{$X^{2}$} \\
\hline & & & & & & & $\%$ & \\
\hline \multirow{4}{*}{ Gözlemler } & Eğitim Fakültesi & 11 & $\% 7$ & 30 & $\% 19,4$ & 114 & $\% 73,5$ & \multirow[t]{4}{*}{$000^{*}$} \\
\hline & Fen Edebiyat & 12 & $\% 18$ & 10 & $\% 15$ & 45 & $\% 67,2$ & \\
\hline & Lisansüstü & 2 & $\% 6,5$ & 5 & $\% 16$ & 24 & $\% 77,4$ & \\
\hline & Toplam & 25 & & 45 & & 183 & & \\
\hline \multirow{4}{*}{$\begin{array}{c}\text { Port- } \\
\text { folyolar }\end{array}$} & Eğitim Fakültesi & 13 & $\% 8,4$ & 117 & $\% 75,5$ & 25 & $\% 16,1$ & \multirow{4}{*}{,000* } \\
\hline & Fen Edebiyat & 16 & $\% 24$ & 38 & $\% 56,7$ & 13 & $\% 19,4$ & \\
\hline & Lisansüstü & 8 & $\% 25,7$ & 12 & $\% 38,7$ & 11 & $\% 35,5$ & \\
\hline & Toplam & 37 & & 167 & & 49 & & \\
\hline \multirow{4}{*}{$\begin{array}{l}\text { Kendini } \\
\text { Değer- } \\
\text { lendirme }\end{array}$} & Eğitim Fakültesi & 12 & $\% 7,7$ & 73 & $\% 47,1$ & 70 & $\% 45,2$ & \multirow[t]{4}{*}{ 291 } \\
\hline & Fen Edebiyat & 8 & $\% 11,9$ & 24 & $\% 35,8$ & 35 & $\% 52,2$ & \\
\hline & Lisansüstü & 2 & $\% 6,5$ & 10 & $\% 32,3$ & 19 & $\% 61,3$ & \\
\hline & Toplam & 22 & & 107 & & 124 & & \\
\hline \multirow{4}{*}{$\begin{array}{c}\text { Yaşıtını } \\
\text { Değer- } \\
\text { lendirme }\end{array}$} & Eğitim Fakültesi & 35 & $\% 22,6$ & 91 & $\% 58,7$ & 29 & $\% 18,7$ & \multirow[t]{4}{*}{,064 } \\
\hline & Fen Edebiyat & 17 & $\% 25,4$ & 28 & $\% 41,8$ & 22 & $\% 32,8$ & \\
\hline & Lisansüstü & 4 & $\% 12,9$ & 17 & $\% 54,8$ & 10 & $\% 32,3$ & \\
\hline & Toplam & 56 & & 136 & & 61 & & \\
\hline \multirow{4}{*}{ Projeler } & Ĕ̆itim Fakültesi & 6 & $\% 3,9$ & 100 & $\% 64,5$ & 49 & $\% 31,6$ & \multirow[t]{4}{*}{809} \\
\hline & Fen Edebiyat & 3 & $\% 4,5$ & 38 & $\% 56,7$ & 26 & $\% 38,8$ & \\
\hline & Lisansüstü & 2 & $\% 6,5$ & 19 & $\% 61,3$ & 10 & $\% 32,3$ & \\
\hline & Toplam & 11 & $\%$ & 157 & & 85 & & \\
\hline \multirow{4}{*}{$\begin{array}{l}\text { Hikaye } \\
\text { Tekrarlı } \\
\text { Anlatım }\end{array}$} & Eğitim Fakültesi & 49 & $\% 31,6$ & 94 & $\% 60,6$ & 12 & $\% 7,7$ & \multirow[t]{4}{*}{114} \\
\hline & Fen Edebiyat & 22 & $\% 32,8$ & 36 & $\% 53,7$ & 9 & $\% 13,4$ & \\
\hline & Lisansüstü & 11 & $\% 35,5$ & 13 & $\% 41,9$ & 7 & $\% 22,6$ & \\
\hline & Toplam & 82 & & 143 & & 28 & & \\
\hline \multirow{4}{*}{$\begin{array}{l}\text { Dramatize } \\
\text { Etme }\end{array}$} & Eğitim Fakültesi & 14 & $\% 9$ & 85 & $\% 55$ & 56 & $\% 36,1$ & \multirow[t]{4}{*}{,099 } \\
\hline & Fen Edebiyat & 11 & $\% 16,4$ & 35 & $\% 52,2$ & 21 & $\% 31,3$ & \\
\hline & Lisansüstü & 6 & $\% 19,4$ & 10 & $\% 32,3$ & 15 & $\% 48,4$ & \\
\hline & Toplam & 31 & & 130 & & 92 & & \\
\hline \multirow[t]{4}{*}{ Oyunlar } & Eğitim Fakültesi & 2 & $\% 1,3$ & 62 & $\% 40$ & 91 & $\% 58,7$ & \multirow[t]{4}{*}{062} \\
\hline & Fen Edebiyat & 4 & $\% 6$ & 36 & $\% 53,7$ & 27 & $\% 40,3$ & \\
\hline & Lisansüstü & 1 & $\% 3,2$ & 15 & $\% 48,4$ & 15 & $\% 48,4$ & \\
\hline & Toplam & 7 & & 113 & 133 & & & \\
\hline
\end{tabular}




\begin{tabular}{|c|c|c|c|c|c|c|c|c|}
\hline \multirow{4}{*}{$\begin{array}{l}\text { Günlükler } \\
\text { Dergiler }\end{array}$} & Eğitim Fakültesi & 76 & $\% 49$ & 75 & $\% 48,4$ & 4 & $\% 2,6$ & \multirow[t]{4}{*}{$000^{*}$} \\
\hline & Fen Edebiyat & 24 & $\% 35,8$ & 41 & $\% 61$ & 2 & $\% 3$ & \\
\hline & Lisansüstü & 8 & 25,8 & 16 & $\% 51,6$ & 7 & $\% 22,6$ & \\
\hline & Toplam & 108 & & 132 & & 13 & & \\
\hline \multirow{4}{*}{$\begin{array}{c}\text { Gösterim- } \\
\text { ler }\end{array}$} & Eğitim Fakültesi & 16 & $\% 10,3$ & 89 & $\% 57,4$ & 50 & $\% 32,3$ & \multirow[t]{4}{*}{$033^{*}$} \\
\hline & Fen Edebiyat & 8 & $\% 11,9$ & 29 & $\% 43,3$ & 30 & $\% 45$ & \\
\hline & Lisansüstü & 6 & $\% 19,4$ & 9 & $\% 29$ & 16 & $\% 51,6$ & \\
\hline & Toplam & 30 & & 127 & & 96 & & \\
\hline \multirow[t]{4}{*}{ Sergiler } & Eğitim Fakültesi & 89 & $\% 57,4$ & 64 & $\% 41$ & 2 & $\% 1,3$ & \multirow[t]{4}{*}{, $033^{\prime}$} \\
\hline & Fen Edebiyat & 26 & $\% 38,8$ & 36 & $\% 53,7$ & 5 & $\% 7,5$ & \\
\hline & Lisansüstü & 17 & $\% 54,8$ & 13 & $\% 41,9$ & 1 & $\% 3,2$ & \\
\hline & Toplam & 132 & & 113 & & 8 & & \\
\hline \multirow{4}{*}{$\begin{array}{l}\text { Kon- } \\
\text { feranslar }\end{array}$} & Eğitim Fakültesi & 80 & $\% 52$ & 67 & $\% 43,5$ & 7 & $\% 4,5$ & \multirow[t]{4}{*}{,125 } \\
\hline & Fen Edebiyat & 32 & $\% 47,7$ & 29 & $\% 43,3$ & 6 & $\% 9$ & \\
\hline & Lisansüstü & 10 & $\% 32,3$ & 19 & $\% 61,3$ & 2 & $\% 6,5$ & \\
\hline & Toplam & 122 & & 115 & & 15 & & \\
\hline \multirow{4}{*}{$\begin{array}{l}\text { Sesli } \\
\text { Düşünme }\end{array}$} & Eğitim Fakültesi & 40 & $\% 25,8$ & 86 & $\% 55,5$ & 29 & $\% 18,7$ & \multirow[t]{4}{*}{ 182 } \\
\hline & Fen Edebiyat & 20 & $\% 29,9$ & 34 & $\% 50,7$ & 13 & $\% 19,4$ & \\
\hline & Lisansüstü & 14 & $\% 50$ & 10 & $\% 32,3$ & 7 & $\% 22,6$ & \\
\hline & Toplam & 74 & & 129 & & 49 & & \\
\hline \multirow[t]{4}{*}{ Tartışma } & Eğitim Fakültesi & 14 & $\% 9,3$ & 88 & $\% 58,3$ & 49 & $\% 32,5$ & \multirow[t]{4}{*}{051} \\
\hline & Fen Edebiyat & 8 & $\% 11,9$ & 43 & $\% 64,2$ & 16 & $\% 24$ & \\
\hline & Lisansüstü & 0 & $\% 0,0$ & 15 & $\% 48,4$ & 16 & $\% 51,5$ & \\
\hline & Toplam & 22 & & 146 & & 81 & & \\
\hline
\end{tabular}

Tablo 4' de İngilizce öğretmenlerinin alternatif ölçme ve değerlendirme yöntemlerini kullanım sıklıkları ile mezun oldukları okullar arasında anlamlı farklılıklar görülmüştür. Portfolyo yöntemi kullanımını fen edebiyat fakültesi mezunu öğretmenlerin \%24'ü hiçbir zaman şeklinde cevaplandırırken eğitim fakültesi mezunu olanların $\% 75,5$ 'i bazen şeklinde cevap vermiştir. Eğitim fakültesi mezunu öğretmenlerin \%18,7'si yaşıtını değerlendirme alternatif yöntemini kullanım sıklıklarını her zaman şeklinde ifade ederken Fen Edebiyat mezunu öğretmenlerin ise \%32,8'i her zaman şeklinde yanıtlamıştır. Lisansüstü mezunu öğretmenler ise bu yöntemi kullanım sıklıklarını bazen olarak belirtmişlerdir. Proje yöntemi kullanım sıklığına ise hem Eğitim Fakültesi hem Fen Edebiyat Fakültesi mezunu öğretmenlerin \%64 ve \% 56 olmak üzere büyük bir kısmı bazen kullanırım yanıtını vermiştir. Aynı şekilde hem Eğitim Fakültesi hem Fen Edebiyat Fakültesi mezunu öğretmenlerin çoğunluğu hikaye tekrarlı anlatımı bazen kullanırken, her zaman kullanma yanıtına bakıldığında Fen Edebiyat fakültesi mezunlarının bu yöntemi eğitim fakültesi mezunlarına 
göre daha çok kullandıkları görülmüştür. Lisansüstü mezun öğretmenler ise bu yöntemi her zaman kullananlar arasında ilk sırada yer almaktadır. Dramatize etme yöntemini kullanma sıklığına bakıldığında Eğitim Fakültesi mezunu öğretmenlerin $\% 55$ 'i bazen yanıtını verirken Fen Edebiyat mezunu öğretmenlerin de $\% 52$ 'si bazen şeklinde yanıt vermiştir. Bu yöntemi eğitim fakültesi mezunlarının her zaman tercih etme oranı \%36 iken Fen Edebiyat mezunlarının \%31 olarak görülmektedir. Günlükler ve dergiler kullanımı sıklığına bakıldığında ise Eğitim Fakültesi mezunlarının \%49'u hiçbir zaman cevabını verirken, Fen Edebiyat mezunlarının \%61'i ve lisansüstü mezunların \%51,6'sıbazen cevabını vermiştir. Gösterimlerin kullanım sıklığında Eğitim Fakültesi mezunlarının \%57,4'ü bazen Fen Edebiyat mezunlarının ise \%45'i her zaman yanıtını vermiştir. Sergi yöntemi kullanım sıklığında Eğitim Fakültesi mezunlarının \%57,4'ü hiçbir zaman, konferans yönteminde de aynı şekilde Eğitim Fakültesi mezunlarının \%52'si ve Fen Edebiyat mezunlarının $\% 47,7$ 'si hiçbir zaman yanıtını vermiştir. Sesli düşünme yöntemini bazen tercih eden \%58,3 çoğunluk Eğitim Fakültesi mezunu öğretmenler iken tartışma yöntemini \%64,2 ile Fen Edebiyat mezunu öğretmenlerin bazen tercih ettiği görülmüştür. Tartışma yöntemini her zaman tercih eden grubun lisansüstü mezunu öğretmenler olduğu görülmektedir.

Tablo 5. İngilizce öğretmenlerinin geleneksel değerlendirme yöntemlerini mezun oldukları okullara göre kullanım sıklıkları.

\begin{tabular}{|c|c|c|c|c|c|c|c|c|}
\hline \multirow{2}{*}{$\begin{array}{l}\text { Değer- } \\
\text { lendirme } \\
\text { Türü }\end{array}$} & \multirow[t]{2}{*}{ Gruplar } & \multicolumn{2}{|c|}{$\begin{array}{l}\text { Hiçbir Za- } \\
\text { man }\end{array}$} & \multirow{2}{*}{\multicolumn{2}{|c|}{$\begin{array}{l}\text { Bazen } \\
\text { f\% }\end{array}$}} & \multicolumn{2}{|c|}{ Her zaman } & \multirow[t]{2}{*}{$\mathbf{X}^{2}$} \\
\hline & & $\begin{array}{l}\text { mar } \\
\mathrm{f} \%\end{array}$ & & & & $\mathrm{f}$ & $\%$ & \\
\hline Yazılı & Eğitim Fakültesi & 10 & $\% 6,5$ & 20 & $\% 13$ & 123 & $\% 80,4$ & ,085 \\
\hline \multirow[t]{3}{*}{ Yoklama } & Fen Edebiyat & 3 & $\% 4,5$ & 16 & $\% 24$ & 48 & $\% 71,6$ & \\
\hline & Lisansüstü & 4 & $\% 13$ & 8 & $\% 25,8$ & 19 & $\% 61,3$ & \\
\hline & Toplam & 17 & & 44 & & 190 & & \\
\hline Sözlü & Eğitim Fakültesi & 10 & $\% 6,5$ & 66 & $\% 42,6$ & 79 & $\% 51$ & , \\
\hline \multirow[t]{3}{*}{ Yoklama } & Fen Edebiyat & 14 & $\% 21$ & 30 & $\% 45$ & 23 & $\% 34,3$ & $007^{*}$ \\
\hline & Lisansüstü & 6 & $\% 19,4$ & 15 & $\% 48,4$ & 10 & $\% 32,3$ & \\
\hline & Toplam & 30 & & 111 & & 112 & & \\
\hline Çoktan & Eğitim Fakültesi & 13 & $\% 8,4$ & 81 & $\% 52,3$ & 61 & $\% 39,4$ &, $025^{*}$ \\
\hline Seçmeli & Fen Edebiyat & 3 & $\% 4,5$ & 29 & $\% 43,3$ & 35 & $\% 52,2$ & \\
\hline \multirow[t]{2}{*}{ Test } & Lisansüstü & 0 & $\% 0$ & 23 & $\% 74,2$ & 8 & $\% 25,8$ & \\
\hline & Toplam & 16 & & 133 & & 104 & & \\
\hline
\end{tabular}




\begin{tabular}{lllllllll}
\hline Doğru & Eğitim Fakültesi & 3 & $\% 2$ & 81 & $\% 52,3$ & 71 & $\% 46$ &, $023^{*}$ \\
Yanlış & Fen Edebiyat & 6 & $\% 9$ & 26 & $\% 38,8$ & 35 & $\% 52$ & \\
& Lisansüstü & 2 & $\% 6,5$ & 20 & $\% 64,5$ & 9 & $\% 29$ & \\
& Toplam & 11 & & 127 & & 115 & & \\
\hline Kisa & Eğitim Fakültesi & 3 & $\% 2$ & 74 & $\% 47,7$ & 78 & $\% 50,3$ & \\
Cevaplı & Fen Edebiyat & 4 & $\% 6$ & 28 & $\% 42$ & 35 & $\% 52,2$ &, 327 \\
Sorular & Lisansüstü & 2 & $\% 6,5$ & 17 & $\% 54,8$ & 12 & $\% 38,7$ & \\
& Toplam & 9 & & 119 & & 125 & & \\
\hline Eşleştirme & Eğitim Fakültesi & 2 & $\% 1,3$ & 63 & $\% 40,6$ & 90 & $\% 58$ &, 112 \\
Soruları & Fen Edebiyat & 0 & $\% 0$ & 21 & $\% 31,3$ & 46 & $\% 68,7$ & \\
& Lisansüstü & 1 & $\% 3,2$ & 17 & $\% 54,8$ & 13 & $\% 42$ & \\
& Toplam & 3 & & 101 & & 149 & & \\
\hline
\end{tabular}

Tablo 5' de İngilizce öğretmenlerinin geleneksel değerlendirme yöntemlerini kullanım sıklıkları ile ilgili veriler bulunmaktadır. Öğretmenlerin mezun oldukları okullar ve geleneksel değerlendirme yöntemlerinden sözlü yoklama, çoktan seçmeli test ve doğru yanlış yöntemlerini kullanım sıkları arasında anlamlı farklılıklar görülmektedir. Eğitim Fakültesi mezunu öğretmenlerin \%51'i sözlü yoklama yöntemini her zaman tercih ederken çoktan seçmeli testi \%52,2 ile doğru yanlış yöntemini ise yine $\% 52$ ile en fazla Fen Edebiyat mezunlarının tercih ettiği görülmektedir.

Tablo 6. Ingilizce öğretmenlerinin alternatif ölçme ve değerlendirme yöntemlerini lisansta ölçme değerlendirme dersi alma durumuna göre kullanım sıklıkları

\begin{tabular}{|c|c|c|c|c|c|c|c|c|}
\hline \multirow{2}{*}{$\begin{array}{l}\text { Değer- } \\
\text { lendirme } \\
\text { Türü }\end{array}$} & \multirow[t]{2}{*}{ Gruplar } & \multirow{2}{*}{$\begin{array}{l}\text { Hiçbir } \\
\text { man } \\
\text { f\% }\end{array}$} & \multirow[t]{2}{*}{ Za- } & \multirow{2}{*}{\multicolumn{2}{|c|}{$\begin{array}{l}\text { Bazen } \\
\mathrm{f} \%\end{array}$}} & \multicolumn{2}{|c|}{ Her zaman } & \multirow[b]{2}{*}{$\mathrm{X}^{2}$} \\
\hline & & & & & & $\mathrm{f}$ & $\%$ & \\
\hline \multirow{3}{*}{ Gözlemler } & Evet & 24 & 10,4 & 42 & 18,3 & 164 & 71 & \multirow{3}{*}{479} \\
\hline & Hayır & 1 & 4,3 & 3 & 13 & 19 & 82,6 & \\
\hline & Toplam & 25 & & 45 & & 183 & & \\
\hline \multirow{3}{*}{ Portfolyolar } & Evet & 31 & 13,5 & 154 & 67 & 45 & 19,6 & \multirow{3}{*}{,263 } \\
\hline & Hayır & 6 & 26,1 & 13 & 56,5 & 4 & 17,4 & \\
\hline & Toplam & 37 & & 167 & & 49 & & \\
\hline \multirow{3}{*}{$\begin{array}{l}\text { Kendini } \\
\text { Değer- } \\
\text { lendirme }\end{array}$} & Evet & 18 & 7,8 & 100 & 43,5 & 112 & 49 & \multirow{3}{*}{,213 } \\
\hline & Hayır & 4 & 17,4 & 7 & 30,4 & 12 & 52 & \\
\hline & Toplam & 22 & & 107 & & 124 & & \\
\hline \multirow{3}{*}{$\begin{array}{l}\text { Yaşıtını } \\
\text { Değer- } \\
\text { lendirme }\end{array}$} & Evet & 50 & 22 & 128 & 56 & 52 & 22,6 & \multirow{3}{*}{ 120 } \\
\hline & Hayır & 6 & 26 & 8 & 35 & 9 & 39 & \\
\hline & Toplam & 56 & & 136 & & 61 & & \\
\hline \multirow{3}{*}{ Projeler } & Evet & 6 & 2,6 & 146 & 63,5 & 78 & 34 & \multirow{3}{*}{, $000^{*}$} \\
\hline & Hayır & 5 & 21,7 & 11 & 48 & 7 & 30,4 & \\
\hline & Toplam & 11 & & 157 & & 85 & & \\
\hline
\end{tabular}




\begin{tabular}{|c|c|c|c|c|c|c|c|c|}
\hline Hikaye & Evet & 75 & 32,6 & 129 & 56 & 26 & 11 & \multirow{3}{*}{, 885} \\
\hline Tekrarlı An- & Hayır & 7 & 30,4 & 14 & 61 & 2 & 9 & \\
\hline & Toplam & 82 & & 143 & & 28 & & \\
\hline \multirow{3}{*}{$\begin{array}{l}\text { Dramatize } \\
\text { Etme }\end{array}$} & Evet & 26 & 11 & 117 & 51 & 87 & 38 & \multirow{3}{*}{ 176 } \\
\hline & Hayır & 5 & 22 & 13 & 56 & 5 & 22 & \\
\hline & Toplam & 31 & & 130 & & 92 & & \\
\hline \multirow{3}{*}{ Oyunlar } & Evet & 4 & 2 & 100 & 43,5 & 126 & 55 & \multirow[b]{3}{*}{, $002^{*}$} \\
\hline & Hayır & 3 & 13 & 13 & 56,5 & 7 & 30,4 & \\
\hline & Toplam & 7 & & 113 & & 133 & & \\
\hline \multirow{3}{*}{$\begin{array}{l}\text { Günlükler } \\
\text { Dergiler }\end{array}$} & Evet & 99 & 43 & 120 & 52,2 & 11 & 4,8 & \multirow{3}{*}{,705 } \\
\hline & Hayır & 9 & 39 & 12 & 52,2 & 2 & 8,7 & \\
\hline & Toplam & 108 & & 167 & & 13 & & \\
\hline \multirow[t]{3}{*}{ Gösterimler } & Evet & 25 & 11 & 113 & 49 & 92 & 40 & \multirow{3}{*}{,065 } \\
\hline & Hayır & 5 & 22 & 14 & 61 & 4 & 17,4 & \\
\hline & Toplam & 30 & & 127 & & 96 & & \\
\hline \multirow{3}{*}{ Sergiler } & Evet & 120 & 52 & 103 & 45 & 7 & 3 & \multirow{3}{*}{,942 } \\
\hline & Hayır & 12 & 52 & 10 & 43,5 & 1 & 4 & \\
\hline & Toplam & 132 & & 113 & & 8 & & \\
\hline \multirow{3}{*}{ Konferanslar } & Evet & 111 & 48,5 & 105 & 46 & 13 & 6 & \multirow{3}{*}{, 840} \\
\hline & Hayır & 11 & 48 & 10 & 43,5 & 2 & 9 & \\
\hline & Toplam & 122 & & 115 & & & & \\
\hline \multirow{3}{*}{$\begin{array}{l}\text { Sesli } \\
\text { Düşünme }\end{array}$} & Evet & 64 & 28 & 117 & 51 & 49 & 21 & \multirow{3}{*}{, $034^{*}$} \\
\hline & Hayır & 10 & 43,5 & 13 & 56,5 & 0 & 0 & \\
\hline & Toplam & 74 & & 130 & & 49 & & \\
\hline \multirow[t]{3}{*}{ Tartışmalar } & Evet & 22 & 10 & 126 & 56 & 78 & 34,5 & \multirow{3}{*}{, $013^{*}$} \\
\hline & Hayır & 0 & 0 & 20 & 87 & 3 & 13 & \\
\hline & Toplam & & & 146 & & 81 & & \\
\hline
\end{tabular}

Tablo 6'daki veriler incelendiğinde lisans eğitimi sürecinde ölçme ve değerlendirme dersi alan ve almayan İngilizce öğretmenlerinin alternatif değerlendirme yöntemleri kullanım sıklıları farklılıklar göstermektedir. Bu farklılaşma projeler, oyunlar, sesli düşünme ve tartışma yöntemlerinde göze çarpmaktadır. Ölçme ve değerlendirme dersi alan öğretmenlerin \%55'i oyunlar yöntemini her zaman tercih ederken bu dersi almayanların $\% 56$ 'sı bu yöntemi bazen tercih ettiklerini belirtmiştir.

$\mathrm{Bu}$ dersi almayan öğretmenlerin çoğunluğu yani \%56'sı sesli düşünmeyi \%87'si ise tartı̧̧malar yöntemini bazen kullandıklarını belirtmiştir. Ölçme değerlendirme dersi almış öğretmenlerin hem sesli düşünme hem de tartışma yöntemini kullanım sıklığı en yüksek "bazen" yanitındadır. 
Tablo 7. Ingilizce öğretmenlerinin geleneksel değerlendirme yöntemlerini lisansta ölçme ve değerlendirme dersi alma durumlarına göre kullanım sıklıkları.

\begin{tabular}{|c|c|c|c|c|c|c|c|c|}
\hline \multirow{2}{*}{$\begin{array}{l}\text { Değer- } \\
\text { lendirme } \\
\text { Türü }\end{array}$} & \multirow[t]{2}{*}{ Gruplar } & \multirow{2}{*}{$\begin{array}{l}\text { Hiçbir } \\
\text { man } \\
\mathrm{f} \%\end{array}$} & \multirow[t]{2}{*}{$\mathrm{Za}-$} & \multirow{2}{*}{\multicolumn{2}{|c|}{$\begin{array}{l}\text { Bazen } \\
\mathrm{f} \%\end{array}$}} & \multicolumn{2}{|c|}{ Her zaman } & \multirow{2}{*}{$\mathrm{X}^{2}$} \\
\hline & & & & & & $\mathrm{f}$ & $\%$ & \\
\hline \multirow{3}{*}{$\begin{array}{l}\text { Yazılı } \\
\text { Yoklama }\end{array}$} & Evet & 17 & 7,5 & 36 & 16 & 175 & 77 & \multirow{3}{*}{, $041^{*}$} \\
\hline & Hayır & 0 & 0 & 8 & 35 & 15 & 65 & \\
\hline & Toplam & 17 & & 44 & & 190 & & \\
\hline \multirow{3}{*}{$\begin{array}{l}\text { Sözlü } \\
\text { Yoklama }\end{array}$} & Evet & 29 & 12,6 & 94 & 41 & 107 & 46,5 & \multirow{3}{*}{, $010^{*}$} \\
\hline & Hayır & 1 & 4,3 & 17 & 74 & 5 & 21,7 & \\
\hline & Toplam & 30 & & 111 & & 112 & & \\
\hline \multirow{3}{*}{$\begin{array}{l}\text { Çoktan } \\
\text { Seçmeli } \\
\text { Test }\end{array}$} & Evet & 14 & 6 & 122 & 53 & 94 & 10 & \multirow{3}{*}{832} \\
\hline & Hayır & 2 & 8,7 & 11 & 48 & 10 & 43,5 & \\
\hline & Toplam & 16 & & 133 & & 104 & & \\
\hline \multirow{3}{*}{$\begin{array}{l}\text { Doğru-Yanlış } \\
\text { Soruları }\end{array}$} & Evet & 10 & 4,3 & 114 & 49,6 & 106 & 46 & \multirow{3}{*}{809} \\
\hline & Hayır & 1 & 4,3 & 13 & 56,5 & 9 & 39 & \\
\hline & Toplam & 11 & & 127 & & 115 & & \\
\hline \multirow{3}{*}{$\begin{array}{l}\text { Kisa Cevapli } \\
\text { Sorular }\end{array}$} & Evet & 9 & 4 & 104 & 45 & 117 & 51 & \multirow{3}{*}{ 152 } \\
\hline & Hayır & 0 & 0 & 15 & 65 & 8 & 35 & \\
\hline & Toplam & 9 & & 119 & & 125 & & \\
\hline \multirow{3}{*}{$\begin{array}{l}\text { Eşleştirme } \\
\text { Soruları }\end{array}$} & Evet & 3 & 1,3 & 88 & 38 & 139 & 60,4 & \multirow{3}{*}{,216 } \\
\hline & Hayır & 0 & 0 & 13 & 56,5 & 149 & 43,5 & \\
\hline & Toplam & 3 & & 101 & & & & \\
\hline
\end{tabular}

Lisans eğitiminde ölçme ve değerlendirme dersi almış İngilizce öğretmenlerinin hepsi yazılı ve sözlü yoklama yöntemlerini \%77 ve \%46'lık bir oranla her zaman kullandıklarını belirtmiştir. Dersi almayan öğretmenlerin ise bu yöntemleri bazen kullandıkları görülmektedir. Aynı zamanda ölçme dersi almamış öğretmenlerin hepsinin yazılı yoklama yöntemini hiçbir zaman tercih etmedikleri görülmektedir.

Tablo 8' de İngilizce öğretmenlerinin alternatif ölçme ve değerlendirme yöntemlerini kullanım sıklıkları ile hizmet içi eğitimlerde ölçme ve değerlendirme dersi almış olma durumları arasında anlamlı farklılıklar görülmüştür. Ölçme ve değerlendirme ile ilgili hizmet içi eğitim almamış öğretmenlerin gözlem yöntemini bu eğitimi alan öğretmenlere göre daha çok kullandıkları görülmektedir. Aynı şekilde projelerde de ölçme ve değerlendirme hizmet içi eğitimi almayan öğretmenlerin bu yöntemi daha çok tercih ettikleri görülmektedir. 
İngilizce Öğretmenlerinin Alternatif Değerlendirme Yöntemlerini Kullanma Yeterliliklerinin İncelenmesi

Tablo 8. Ingilizce öğretmenlerinin alternatif ölçme ve değerlendirme yöntemlerini hizmet içi eğitimlerde ölçme değerlendirme dersi alma durumuna göre kullanım siklıkları.

\begin{tabular}{|c|c|c|c|c|c|c|c|c|}
\hline \multirow{2}{*}{$\begin{array}{l}\text { Değerlendirme } \\
\text { Türüi }\end{array}$} & \multirow[t]{2}{*}{ Gruplar } & \multirow{2}{*}{\multicolumn{2}{|c|}{$\begin{array}{l}\text { Hiçbir Zaman } \\
\mathrm{f} \%\end{array}$}} & \multirow{2}{*}{\multicolumn{2}{|c|}{$\begin{array}{l}\text { Bazen } \\
\mathrm{f} \%\end{array}$}} & \multicolumn{2}{|c|}{ Her zaman } & \multirow{2}{*}{$X^{2}$} \\
\hline & & & & & & $\mathrm{f}$ & $\%$ & \\
\hline \multirow{3}{*}{ Gözlemler } & Evet & 2 & 3,6 & 17 & 30,4 & 37 & 66 & \multirow{3}{*}{, $008^{*}$} \\
\hline & Hayır & 23 & 11,7 & 28 & 14,2 & 146 & 74 & \\
\hline & Toplam & 25 & & 45 & & 183 & & \\
\hline \multirow{3}{*}{ Portfolyolar } & Evet & 9 & 16 & 36 & 64,3 & 11 & 19,6 & \multirow{3}{*}{,933 } \\
\hline & Hayır & 28 & 14 & 131 & 66,5 & 38 & 19,3 & \\
\hline & Toplam & 37 & & 167 & & 49 & & \\
\hline \multirow{3}{*}{$\begin{array}{l}\text { Kendini } \\
\text { Değerlendirme }\end{array}$} & Evet & 5 & 9 & 18 & 32 & 33 & 59 & \multirow{3}{*}{ 202 } \\
\hline & Hayır & 17 & 8,6 & 89 & 45,2 & 91 & 46,2 & \\
\hline & Toplam & 22 & & 107 & & 124 & & \\
\hline \multirow{3}{*}{$\begin{array}{l}\text { Yaşıtını Değer- } \\
\text { lendirme }\end{array}$} & Evet & 8 & 14 & 30 & 53,6 & 18 & 32 & \multirow{3}{*}{ 140 } \\
\hline & Hayır & 48 & 24 & 106 & 54 & 43 & 22 & \\
\hline & Toplam & 56 & & 136 & & 61 & & \\
\hline \multirow{3}{*}{ Projeler } & Evet & 6 & 10,7 & 33 & 59 & 17 & 30,4 & \multirow{3}{*}{, $030^{*}$} \\
\hline & Hayır & 5 & 2,5 & 124 & 63 & 68 & 34,5 & \\
\hline & Toplam & 11 & & 157 & & 85 & & \\
\hline \multirow{3}{*}{$\begin{array}{l}\text { Hikaye } \\
\text { Tekrarlı } \\
\text { latım }\end{array}$} & Evet & 8 & 14,3 & 34 & 60,7 & 14 & 25 & \multirow{3}{*}{, $000^{*}$} \\
\hline & Hayır & 74 & 37,6 & 109 & 55,3 & 14 & 7 & \\
\hline & Toplam & 82 & & 143 & & 28 & & \\
\hline \multirow{3}{*}{$\begin{array}{l}\text { Dramatize } \\
\text { Etme }\end{array}$} & Evet & 2 & 10,7 & 24 & 43 & 26 & 46,4 & \multirow{3}{*}{,206 } \\
\hline & Hayır & 5 & 12,7 & 106 & 54 & 66 & 33,5 & \\
\hline & Toplam & 7 & & 130 & & 92 & & \\
\hline \multirow{3}{*}{ Oyunlar } & Evet & 2 & 3,6 & 33 & 59 & 21 & 37,5 & \multirow{3}{*}{, $038^{*}$} \\
\hline & Hayır & 5 & 2,5 & 80 & 40,6 & 112 & 57 & \\
\hline & Toplam & 7 & & 113 & & 133 & & \\
\hline \multirow{3}{*}{$\begin{array}{l}\text { Günlükler } \\
\text { Dergiler }\end{array}$} & Evet & 13 & 23 & 37 & 66 & 6 & 10,7 & \\
\hline & Hayır & 95 & 48 & 95 & 48 & 7 & 3,6 &, $001^{*}$ \\
\hline & Toplam & 108 & & 167 & & 13 & & \\
\hline & Evet & 3 & 5,4 & 31 & 55,4 & 22 & 39,3 & \\
\hline Gösterimler & Hayır & 27 & 13,7 & 96 & 48,7 & 74 & 37,6 & \\
\hline & Toplam & 30 & & 127 & & 96 & &, 226 \\
\hline Sergiler & Evet & 17 & 30,4 & 39 & 69,6 & 0 & 0 & \\
\hline & Hayır & 115 & 58,4 & 74 & 37,6 & 8 & 4 &, $000^{*}$ \\
\hline & Toplam & 132 & & 113 & & 8 & & \\
\hline & Evet & 18 & 32,7 & 35 & 63,6 & 2 & 3,6 & \\
\hline Konferanslar & Hayır & 104 & 53 & 80 & 40,6 & 13 & 6,6 &, $010^{*}$ \\
\hline & Toplam & 122 & & 115 & & 15 & & \\
\hline & Evet & 14 & 25 & 27 & 48 & 15 & 26,8 & \\
\hline Sesli Düşünme & Hayır & 60 & 30,5 & 103 & 52,3 & 34 & 17,3 & 269 \\
\hline & Toplam & 74 & & 130 & & 49 & & \\
\hline & Evet & 0 & 0 & 30 & 53,6 & 26 & 46,4 & \\
\hline Tartışmalar & Hayır & 22 & 11,4 & 116 & 60 & 55 & 28,5 &, $004^{*}$ \\
\hline & Toplam & 22 & & 146 & & 81 & & \\
\hline
\end{tabular}


Hizmet içi eğitime katılmış olan öğretmenler hikaye tekrarlı anlatım yöntemini 60 bazen ve 25 her zaman yanıtlarıyla daha sık kullanmakta oldukları görülmektedir. Hizmet içi eğitime katılmış öğretmenlerin 59'u oyunları bazen tercih ederken bu kursa katılmamış öğretmenlerin 57 'sinin oyunları her zaman tercih ettikleri görülmektedir. Günlükler/dergilere bakıldığında ise ölçme ve değerlendirme hizmet içi eğitimi alan öğretmenlerinin çoğunluğunun (66) bu yöntemi bazen tercih ettiği hizmet içi eğitimi almamış öğretmenlerin 48 'inin hiçbir zaman diğer 48 'lik dilimin ise bazen tercih ettikleri görülmektedir. Sergiler ve konferanslarda hizmet içi eğitim alan öğretmenlerin çoğunluğunun bu yöntemleri bazen tercih ettikleri görülürken hizmet içi eğitim almayan öğretmenlerin çoğunluğunun ise bu iki yöntemi de hiçbir zaman kullanmadıkları görülmektedir. Son olarak tartışma yöntemine bakıldığında hizmet içi eğitim alan öğretmenlerin 53'ünün bazen 46'sının her zaman olmak üzere bu yöntemi sıklıkla kullandıkları görülürken bu eğitimi almamış öğretmenlerin çoğunluğunun ise tartışmaları bazen kullandıkları görülmektedir.

Tablo 9. İngilizce öğretmenlerinin geleneksel ölçme ve değerlendirme yöntemlerini hizmet içi eğitimlerde ölçme değerlendirme dersi alma durumuna göre kullantm sıklıkları.

\begin{tabular}{|c|c|c|c|c|c|c|c|c|}
\hline \multirow{2}{*}{$\begin{array}{l}\text { Değer- } \\
\text { lendirme } \\
\text { Türü }\end{array}$} & \multirow[t]{2}{*}{ Gruplar } & \multirow{2}{*}{$\begin{array}{l}\text { Hiçbir } \\
\text { man } \\
\text { f\% }\end{array}$} & \multirow[t]{2}{*}{ Za- } & \multirow{2}{*}{\multicolumn{2}{|c|}{$\begin{array}{l}\text { Bazen } \\
\mathrm{f} \%\end{array}$}} & \multicolumn{2}{|c|}{ Her zaman } & \multirow{2}{*}{$\mathbf{X}^{2}$} \\
\hline & & & & & & & $\%$ & \\
\hline \multirow{3}{*}{$\begin{array}{l}\text { Yazılı } \\
\text { Yoklama }\end{array}$} & Evet & 2 & 3,6 & 13 & 23,2 & 41 & 73,2 & \\
\hline & Hayır & 15 & 7,7 & 31 & 16 & 149 & 76,4 & 290 \\
\hline & Toplam & 17 & & 44 & & 190 & & \\
\hline \multirow{3}{*}{$\begin{array}{l}\text { Sözlü } \\
\text { Yoklama }\end{array}$} & Evet & 10 & 18 & 21 & 37,5 & 25 & 46,5 & \\
\hline & Hayır & 20 & 10 & 90 & 45,7 & 87 & 44,2 & 240 \\
\hline & Toplam & 30 & & 111 & & 112 & & \\
\hline Çoktan & Evet & 2 & 3,6 & 27 & 48 & 27 & 48 & \\
\hline Seçmeli & Hayır & 14 & 7,0 & 106 & 54 & 77 & 39 & 367 \\
\hline Test & Toplam & 16 & & 133 & & 104 & & \\
\hline \multirow{3}{*}{$\begin{array}{l}\text { Doğru-Yanlış } \\
\text { Soruları }\end{array}$} & Evet & 0 & 0,0 & 28 & 50 & 28 & 50 & \\
\hline & Hayır & 11 & 5,6 & 99 & 50,3 & 87 & 44,2 & 178 \\
\hline & Toplam & 11 & & 127 & & 115 & & \\
\hline \multirow{3}{*}{$\begin{array}{l}\text { Kisa Cevapli } \\
\text { Sorular }\end{array}$} & Evet & 0 & 0,0 & 27 & 48,2 & 29 & 52 & \\
\hline & Hayır & 9 & 4,6 & 92 & 46,7 & 96 & 48,7 & 264 \\
\hline & Toplam & 9 & & 119 & & 125 & & \\
\hline \multirow{3}{*}{$\begin{array}{l}\text { Eşleştirme } \\
\text { Soruları }\end{array}$} & Evet & 0 & 0,0 & 22 & 39,3 & 34 & 60,7 & \\
\hline & Hayır & 3 & 1,5 & 79 & 40 & 115 & 58,4 & 637 \\
\hline & Toplam & 3 & & 101 & & 149 & & \\
\hline
\end{tabular}


Tablo 9 incelendiğinde İngilizce öğretmenlerinin geleneksel ölçme ve değerlendirme yöntemlerini hizmet içi eğitimlerde ölçme ve değerlendirme dersi alma durumlarına göre kullanım sıklıklarında bir farklılaşma görülmemektedir.

\section{Tartışma ve Sonuç}

Alternatif değerlendirmeler öğrenciyi merkeze alan yaklaşımlardır. Çağdaş öğrenme-öğretme yaklaşımlarını benimseyen okullar genellikle öğreneni merkeze alan öğrenme-öğretme yaklaşımlarını uygulayıp alternatif değerlendirme yaklaşımlarını ve araçlarını tercih etmektedirler (Karaaslan, 2015). Bu yaklaşımlar ve araçlar öğrencinin gerçek yaşamla bilgisi arasında bir bağlantı kurması ve problemlerle karşılaştığı zaman çözüm yolları bulabilmesi için fırsatlar yaratır.Bu araştırmada İngilizce öğretmenlerinin alternatif ölçme ve değerlendirme tekniklerini ne sıklıkta kullandıkları çeşitli değişkenler açısından incelenmiştir ve bununla birlikte yeterlilikleri hakkında fikir sahibi olunmaya çalışılmıştır. Sınıf öğretmenlerinin kullandıkları ölçme değerlendirme tekniklerine bakıldığı zaman alternatif ölçme ve değerlendirmede yol almamıza rağmen öğretmenlerin hala buna uyum sağlayamadığı görülmektedir. Öğretmeler çoğunlukla geleneksel ölçme değerlendirme araçlarını kullanmaktadırlar. İngilizce öğretmenlerinin geneli ise alternatif değerlendirmeler konusunda bilgi sahibi ve yeterli olduğu sadece yöntemleri tercih etme durumlarının farklılaştığ görülmektedir. Hatta bu öğretmenlerin alternatif değerlendirme yöntemiyle birlikte geleneksel yöntemlerin bazılarından da hiç vazgeçmediği sonucuna ulaşılmıştır. Bu durum bilinçli ve yeterlilik düzeyi yüksek olan İngilizce öğretmenlerinin sadece tek bir yönteme odaklanmaktansa öğrencileri değerlendirme sürecinde her iki yöntemi de birlikte kullandığı şeklinde yorumlanabilir. Bu duruma paralel olarak (Fatma Şaşmaz Ören, 2007) yaptığı araştırma da geleneksel ve alternatif değerlendirme yaklaşımlarının bir arada ve aynı sıklıkta kullanıldığının sonucuna ulaşmıştır. Geleneksel ve alternatif değerlendirmeyi farklı bir bakış açısı olarak uzatan eğitim konusu üzerinde inceleyen (Dikli, 2003) ise uzaktan eğitimde alternatif değerlendirme yaklaşımının kullanılmasının gerekliliğini belirtmiştir. 
İngilizce öğretmenlerinin alternatif ölçme ve değerlendirme yöntemlerini cinsiyete göre kullanım sıklıklarından elde edilen verilerle sadece bazı yöntemlerin kullanımlarında cinsiyete göre farklılaşma olduğu sonucuna ulaşılmıştır. Bu yöntemlerden gözlem, oyun ve gösterimleri kadın öğretmenlerin daha çok tercih ettikleri sonucuna ulaşılmıştır. Aynı şekilde geleneksel yöntemlerin kullanım sıklıklarında da cinsiyete göre farklılaşma olduğu sonucuna ulaşılmıştır. Sözlü yoklama, kısa cevap ve doğru yanlış sorularını erkek öğretmenlerin kadınlara göre daha çok tercih ettiği sonucuna ulaşılmıştır. (Kanatlı, 2009) Erkek sınıf öğretmenlerinin alternatif ölçme değerlendirmeye yönelik tutumlarının ve kullanım sıklıklarının kadın öğretmenlere göre daha olumlu olduğu sonucuna ulaşmıştır.(Banoğlu, 2009), (Karaaslan, 2015), (Şahin ve Atasoy, 2018) ve (Akarsu, 2008)' in yapmış oldukları çalışmalarda ise cinsiyetin alternatif değerlendirme yöntemlerini kullanım sıklıklarında bir fark yaratmadığı sonucuna ulaşılmıştır.

İngilizce öğretmenlerinin alternatif ölçme ve değerlendirme yöntemlerini mezun oldukları okullara göre kullanım sıklıkları ile ilgili sonuçlar incelendiğinde ise oyunlar, kendini değerlendirme ve gözlemler hariç diğer bütün yöntemlerde anlamlı farklılıklar olduğu sonucuna ulaşılmıştır. Eğitim fakültesi mezunu öğretmenlerin lisans sürecinde bu yöntemlere yönelik dersler almaları sebebiyle bu yöntemlerin hepsini aktif bir şekilde kullanması beklenirken sadece gösterimler, sergi ve dramatize etmeyi her zaman kullandıkları sonucuna ulaşılmıştır. Eğitim fakültesi mezunlarına kıyasla Fen Edebiyat mezunu olanların yaşıtını değerlendirme, hikaye tekrarlı anlatım ve günlükler/dergiler yöntemlerini daha sık kullandıkları sonucuna ulaşılmıştır. Dikkat çeken sonuçlardan bir diğeri ise tartışma yöntemini her zaman tercih eden grubun sadece lisansüstü mezunu öğretmenlerden oluşmasıdır. Lisansüstü mezunlarının sayıca az olması bu araştırmanın sınırlılıklarından biridir ve bu konuda verimli sonuçlara ulaşılamamıştır. (Çetin, 2011) Yapmış olduğu araştırma sonucunda bu araştırmaya paralel olarak gözlemler ve kendini değerlendirme gibi yöntemleri tüm öğretmenlerin kullandığını, anlamlı bir fark görülmediğini belirtmiştir. (Şahin ve Atasoy, 2018)' in araştırması sonucu da mezun olunan okul türünün alternatif değerlendirme yaklaşımlarına bir etkisi olmadığıdır. (Arseven, 2013) ise yapmış olduğu çalışmada lisansüstü eğitim alan öğretmenlerin alternatif değerlendirme 
yöntemlerini kullanımlarında lisansüstü eğitimin katkı sağladığını belirtmiştir.

İngilizce öğretmenlerinin geleneksel değerlendirme yöntemlerini mezun oldukları okullara göre kullanım sıklıkları ile ilgili elde edilen veriler sonucunda ise sözlü yoklamayı her zaman eğitim fakültesi mezunlarının kullandığı çoktan seçmeli ve doğru yanlış sorularını ise her zaman kullanan çoğunluğun Fen Edebiyat mezunlarına ait olduğu görülmektedir. Diğer yöntemlerde anlamlı bir farka ulaşılmamıştır.

İngilizce öğretmenlerinin lisans eğitimlerinde ölçme değerlendirme dersi alıp almama durumlarına göre alternatif yöntemleri kullanım sıklıkları ile ilgili verilerle bu dersi alan öğretmenlerin alternatif ölçme ve değerlendirme yöntemlerini her zaman kullanmadıkları sonucuna ulaşılmıştır. Sadece oyunları her zaman tercih etmektedirler. Hatta bu öğretmenlerin çoğunlukla geleneksel yöntemlerden yazılı ve sözlü yoklamayı tercih ettikleri görülmüştür. Bu dersi almayan öğretmenlerin hepsinin ise alternatif yöntemleri bazen kullandıkları sonucuna ulaşılırken aynı zamanda yazılı yoklama yöntemini hiçbir zaman kullanmadıkları dikkat çekmektedir.(Arseven, 2013) Üniversitede ölçme ve değerlendirme dersi alan öğretmenlerin bu yöntemleri kullanım sıklıklarına katkısı olduğu sonucuna ulaşmıştır. Bu dersi almayanların ise alternatif değerlendirme yöntemlerine ilişkin bilgilere internet, kitaplar ve diğer öğretmen arkadaşlar aracılığıyla ulaştığını belirtmiştir.

İngilizce öğretmenlerinin alternatif ölçme ve değerlendirme yöntemlerini hizmet içi eğitimlerde ölçme değerlendirme dersi alma durumuna göre kullanım sıklıklarının sonucu bu eğitime katılmış öğretmenlerin doğal olarak alternatif yöntemleri daha çok tercih etmeleri beklenmekteydi. Buna zıt olarak sadece tartışma ve günlükler/dergiler yöntemlerinde bu eğitime katılmış öğretmenler bu alternatif yöntemleri her zaman kullandıklarını belirtmiştir. Hizmet içi eğitim almayan öğretmenler ise gözlemler, projeler ve oyunları kullanma noktasında hizmet içi eğitimi alanlara göre sayıca yüksek olarak bulunmuştur. Yapılan araştırmalar incelendiğinde(Arseven, 2013)'ün çalışma grubundaki öğretmenlerin çoğunun incelenen programda bulunan alternatif değerlendirme yaklaşımlarıyla ilgili olarak herhangi bir eğitime katılmadıkları katılanların çoğunun ise alternatif değerlendirme yaklaşımları hakkında katıldıkları eğitimlerden yeterli verimi alamadıkları sonucuna ulaşılmıştır. 
Son olarak geleneksel değerlendirme hizmet içi eğitimi almak ile öğretmenlerin bu yöntemleri kullanım sıklıkları arasında anlamlı bir fark bulunamamıştır.

\section{Öneriler}

- Öğretmenlerin sınıf içi uygulamaları verilen cevapların güvenilirliği açısından gözlem yapılarak incelenebilir.

- Nitel bir çalışma ile öğretmen görüşlerine ulaşılarak neden alternatif değerlendirme ve geleneksel değerlendirme yöntemlerinin tercih edildiği ve bu noktada öğretmenlerin kendilerini hangi yönlerden güçlü veya zayıf hissettikleri, kendilerini nasıl geliştirebilecekleri konusunda bilgi sahibi olunarak araştırma genişletilebilir.

- Alternatif değerlendirmelere yönelik yapılan araştırmaların çoğunluğunun Fen Ve Teknoloji dersine yönelik olduğu görülmüştür. Bu nedenle İngilizce dersi ile ilgili bu tarz çalışmaların sayısı arttırılabilir.

- Yürütülen çalışma okul kademeleri ve okul türlerine göre detaylandırarak tekrar düzenlenebilir çünkü öğretmenlerin kullandıkları yöntemler sınıf seviyesine ve okul türüne göre farklllık gösterebilmektedir.

- Sadece öğretmenlere sorular yöneltilerek yapılan bu çalışma öğrencilerin gözünden de veriler elde edilerek genişletilebilir. Bu şekilde kullanılan yöntemlerin hangisinin daha verimli olduğu ve öğrenciler açısından tercih edildiği sonucuna da ulaşılabilir. 


\section{EXTENDED ABSTRACT}

\section{Examining The Competencies of English Teachers Using Alternative Assessment Methods}

Mustafa Çelebi - Beyza Nur Kuşuçuran

Erciyes University - Ministry of National Education

Alternative assessments are approaches that center the student. Schools that adopt contemporary learning-teaching approaches generally apply learning-teaching approaches centered on the learner and prefer alternative assessment approaches and tools. These approaches and tools create opportunities for the student to make a connection between real life and knowledge and to find solutions when faced with problems. In this study, the frequency of using alternative evaluation and assessment techniques of English teachers is examined in terms of various variables.

This study was conducted to investigate and examine the frequency of using alternative assessment methods of English teachers according to some variables. For this purpose, the following questions were sought;

1. What are the perceptions of proficiency of English teachers about alternative assessment methods?

2. How often alternative assessment methods (observation, portfolio, self-assessment, peer assessment, project, story-telling, dramatization, games, diaries, screenings, exhibitions, conferences, voice thinking and discussion) used according to;

a) Gender

b) School you graduated from

c) Taking courses related to evaluation and assessment during undergraduate and / or graduate education,

d) the status of attending an in-service training course on evaluation and assessment techniques.

The research is a descriptive study that reveals the current situation in a subject in the general survey type. Screening models are studies that aim to collect data to determine the specific characteristics of a group. 
The universe of this research; In the academic year 2018-2019, which constitutes all English teachers working in primary and secondary school levels in Turkey. The sample consists of 253 English teachers working in these schools. The sample was selected from the study population by simple probability (random) sampling. In the simple probability sampling method, all units in the universe have independent and equal chances for sampling (Büyüköztürk, Kılıç Çakmak, Akgün, Karadeniz and Demirel, 2018).

In the study, a questionnaire was applied about the frequency of using alternative and traditional assessment methods of English teachers as data collection tools. The data collection tool was taken from a previous master thesis and adapted. The data collection tool used was adapted from a master's thesis in the Science Education Department of Yüzüncü Yıl University (Karaaslan, Master Thesis, 2015).

The data obtained as a result of the application was checked and the necessary arrangements were made and then transferred to the computer. The data were analyzed with SPSS program. In the analysis of the data obtained in accordance with the aim of the study, techniques such as frequency and percentage were used in personal information and items for teachers. In addition, cross-tables were used to analyze and interpret the relationships between variables in the study.

When the assessment techniques used by classroom teachers are examined, it is seen that although we have made progress in alternative assessment and evaluation, teachers still cannot adapt to this. Teachers often use traditional assessment tools. On the other hand, English teachers are knowledgeable and sufficient about alternative assessments and it is seen that they prefer only different methods. In fact, it was concluded that these teachers never gave up some of the traditional methods together with the alternative assessment method. This situation can be interpreted as the fact that English teachers who are conscious and have high level of proficiency use both methods together in the process of assessment students rather than focusing on only one method. According to the data obtained from the frequency of using alternative assessment and evaluation methods of English teachers according to gender, it is concluded that there is a gender differentiation in the use of some methods. It was concluded that 
female teachers preferred observations, plays and performances among these methods.

When the results related to the frequency of using English teachers' alternative measurement and evaluation methods according to the schools they graduated from, it is concluded that there are significant differences in all methods except games, self-evaluation and observations. It is concluded that teachers who are graduates of education faculties are expected to use all of these methods actively because they take lessons about these methods in their undergraduate process, but they always use only demostrations, exhibitions and dramatization.

As a result of the frequency of use of English teachers' alternative assessment and evaluation methods according to the status of taking measurement and assessment courses in in-service trainings, it was expected that teachers who participated in this training would naturally prefer alternative methods. In contrast, teachers who participated in this training only in the discussion and diary / journal methods stated that they always use these alternative methods.

Finally, in the use of traditional assessment methods, no significant difference was found between the in-service training and the frequency of teachers using these methods.

\section{Kaynakça / References}

Akarsu, F. (2008). Fizik, kimya ve matematik öğretmenlerinin değerlendirme araçlarıyla ilgili yaklaşımları ve uygulamaları. Eğitim ve Bilim, 33(149), 18-29.

Arseven, Z. (2013, Ağustos). Ilköğretim matematik öğretmenlerinin 2005 matematik öğretim programında yer alan alternatif değerlendirme yaklaşımların uygulayabilme yeterliliklerinin incelenmesi. Yayımlanmamış Yüksek Lisans Tezi, Uludağ Üniversitesi Eğitim Bilimleri Enstitüsü, Bursa.

Banoğlu, C. (2009). Bilişim Teknolojileri Öğretmenlerinin Alternatif Değerlendirme Yöntemlerine Yönelik Yeterlilik Düzeyleri. Yüksek Lisans Tezi, Yıldız Teknik Üniversitesi, Sosyal Bilimler Enstitüsü, İstanbul

Bekci, N. (2009). Fen ve teknoloji öğretmenlerinin alternatif değerlendirme yöntemlerini kullanma yeterliliklerinin araştırılması.Yayımlanmamış Yüksek Lisans Tezi, Gazi Üniversitesi, Eğitim Bilimleri Enstitüsü, Ankara. 
Brooks, J. G., ve Brooks, M. G. (1999). In search of understanding: The case for constructivist classrooms. Alexandria, Virginia USA: Association for Supervision and Curriculum Development, eBook.

Brown, H. D. (2004). Language assessment principles and classroom practices. NY: Longman.

Büyüköztürk, Ş., Çakmak, E. K., Akgün, Ö. E., Karadeniz, Ş., ve Demirel, F. (2018). Bilimsel araştırma yöntemleri. Ankara: Pegem Akademi.

Çetin, L. M. (2011, Mayıs). Çocuklara yabancı dil öğretiminde alternatif değerlendirme yöntemleriyle ilgili bir çalışma. Yayımlanmamış Yüksek Lisans Tezi, Ortadoğu Teknik Üniversitesi, Sosyal Bilimler Enstitüsü, Ankara

Dikli, S. (2003). Assessment at a distance: Traditional vs. alternative assessments. The Turkish Online Journal of Educational Technology, 2(3), 13-19.

Duran, M., Mıhladız, G., ve Ballıel, B. (2013). İlköğretim öğretmenlerinin alternatif değerlendirme yöntemlerine yönelik yeterlik düzeyleri. Mehmet Akif Ersoy Üniversitesi Ĕ̆itim Bilimleri Enstitüsü Dergisi , 2(2), 2637.

Fatma Şaşmaz Ören, N. T. (2007). İlköğretim sınıf öğretmenlerinin alternatif değerlendirme yaklaşımlarına ilişkin görüşleri . Dokuz Eylül Üniversitesi Buca Ĕ̆itim Fakültesi Dergisi , 22, 15-27.

Kanatlı, F. (2009). Alternatif ölçme ve değerlendirme teknikleri konusunda s1nıf öğretmenlerinin görüşlerinin değerlendirilmesi. Mustafa Kemal Üniversitesi Sosyal Bilimler Enstitüsü Dergisi, 6(12), 209-234.

Karaaslan, O. (2015). Fen ve teknoloji öğretmenlerinin alternatif ölçme değerlendirme tekniklerini uygulamadaki yeterlilikleri. Yayımlanmamış Yüksek Lisans Tezi, Yüzüncü Yıl Üniversitesi, Eğitim Bilimleri Enstitüsü, Van

Karip, E., Semerci, Ç., Gündoğdu, K., Sezgin, F., Demircioğlu, G., Köse, E., et al. (2008). Ölçme ve değgrlendirme. Ankara: Pegem Akademi.

Kuran, K. (2009). Alternatif ölçme ve değerlendirme teknikleri konusunda s1nuf öğretmenlerinin görüşlerinin değerlendirilmesi. Mustafa Kemal Üniversitesi Sosyal Bilimler Enstitüsü Dergisi, 6(12), 209-234.

Kutlu, Ö., Doğan, C., ve Karakaya, İ. (2017). Ölçme ve değerlendirme performansa ve portfolyaya dayalı durum belirleme. Ankara: Pegem Akademi.

Nasab, F. G. (2015). Alternative versus traditional assessment. Journal of Applied Linguistics and Language Research, 2(6), 165-178. 
Özenç, M., ve Çakır, M. (2015). Sınıf öğretmenlerinin alternatif ölçme ve değerlendirme yeterliklerinin belirlenmesi. Elementary Education Online, 14(3), 914-933.

Şahin, Ç., ve Öztürk, Y. A. (2014). Sınıf öğretmeni adaylarının alternatif ölçme değerlendirme yöntemlerine ilişkin görüşleri. Kastamonu Ĕ̆itim Dergisi, 22(1), 123-142.

Şahin, M., ve Atasoy, E. (2018). Sosyal bilgiler öğretmenlerinin alternatif ölçme-değerlendirme yöntemlerine yönelik tutumlarının değerlendirilmesi. Uşak Üniversitesi Ĕ̆itim Araştırmaları Dergisi, 4(1), 18-33.

Yiğit, F., ve Kırımlı, B. (2015). Türkçe öğretmenlerinin alternatif ölçme değerlendirme yöntemlerinin işlevleri ve kullanılma sıklığı hakkındaki görüşleri. Milli Ĕ̆itim Dergisi, 45(205), 64-86.

Zelyurt, H., ve Özbek, R. (2018). Alternatif değerlendirme araçlarına yönelik öğretmen görüşleri. İnönü Üniversitesi Ĕ̆itim Fakültesi Dergisi 19(2), 370-396.

\section{Kaynakça Bilgisi / Citation Information}

Çelebi, M. ve Kuşuçuran B. N. (2019). İngilizce öğretmenlerinin alternatif değerlendirme yöntemlerini kullanma yeterliliklerinin incelenmesi. OPUS-Uluslararası Toplum Araştırmaları Dergisi, 13(19), 9831009. DOI: $10.26466 /$ opus. 591260 